\title{
Prevalence study of signs and symptoms of temporomandibular disorder in Brazilian college students
}

\section{Prevalência de sinais e sintomas de disfunção temporomandibular em universitários brasileiros}

\author{
Anamaria Siriani de Oliveira* \\ Elton Matias Dias** \\ Rogério Guimarães Contato*** \\ Fausto Berzin****
}

\begin{abstract}
The aim of this study was to evaluate the prevalence and severity of temporomandibular disorders (TMD) in Brazilian college students. A questionnaire was administered to 2,396 students. Seventy-three percent of women (mean age $21.94 \pm 5$ years) and $27 \%$ of men (mean age $22.41 \pm 4.8$ years) answered the questionnaire. The anamnestic index was used to classify the volunteers according to TMD severity degree. The results showed a higher percentage of men without TMD (43.74\%) ( $<<0.05$, Chi-square test). The women exhibited some degree of severity $(73.03 \%)$ at a higher frequency than men $(56.26 \%)$. No significant differences were observed between sexes for a same TMD severity degree $(p>0.05)$. The results indicated TMD prevalence in Brazilian college students similar to that presented in other studies found in the literature reviewed. Longitudinal studies are recommended to follow the prevalence and health care needs in this population.
\end{abstract}

DESCRIPTORS: Temporomandibular joint disorders; Epidemiology; Questionnaires; Prevalence.

\begin{abstract}
RESUMO: O objetivo deste estudo foi avaliar a prevalência e a severidade da disfunção temporomandibular (DTM) em universitários brasileiros. Participaram do estudo 2.396 estudantes. Responderam ao questionário $73 \%$ de mulheres (21,94 \pm 5 anos) e $27 \%$ de homens (22,41 $\pm 4,8$ anos). O índice anamnésico foi utilizado para classificar os voluntários por nível de severidade da DTM. Os resultados mostraram uma maior porcentagem de homens sem DTM (43,74\%) ( $<<0,05$ teste Qui-quadrado). As mulheres mostraram algum nivel de severidade $(73,03 \%)$ com maior freqüência que os homens $(56,26 \%)$. Não foram evidenciadas diferenças de freqüência entre os sexos classificados com DTM de mesma severidade. Os resultados indicam que a prevalência de DTM em universitários brasileiros é semelhante à de outros trabalhos presentes na literatura. Estudos longitudinais são necessários para acompanhar a prevalência e a necessidade de tratamento nessa população.

DESCRITORES: Transtornos da articulação temporomandibular; Epidemiologia; Questionários; Prevalência.
\end{abstract}

\section{INTRODUCTION}

The expression Temporomandibular disorders (TMD) is a generic designation for a subgroup of orofacial pain disorders. This classification comprises the pain complaints in the temporomandibular joint (TMJ) region, muscle fatigue, especially of the masticatory muscles, impaired jaw movement, and articular sounds. The multifactorial TMD etiology is related to emotional tension, occlusal interferences, teeth loss, postural deviation, masticatory muscular dysfunction, internal and external changes in TMJ structure, and the various associations of these factors ${ }^{6,17}$.
TMD prevalence studies have demonstrated a large amount of people with signs and symptoms in clinical and subclinical degrees. Thus, we have found a high TMD prevalence in non-patients, i.e., among those who do not seek for health care attention $^{22}$. A non-patient prevalence study indicates closely $75 \%$ of subjects with just one TMD sign, and $33 \%$ with at least one symptom ${ }^{7}$. Another estimate related that 50 to $75 \%$ of the evaluated general population would have one TMD sign ${ }^{10}$ and 20 to $25 \%$, one symptom in any life period ${ }^{3}$. TMD severity studies should provide a health care

\footnotetext{
* Physical Therapist, Professor, School of Medicine of Ribeirão Preto, University of São Paulo.

** Physical Therapist, Graduate Student; ${ }^{* * *}$ Chemical Engineer, Professor - University Center of Triângulo.

**** DDS, Professor, School of Dentistry of Piracicaba, State University of Campinas.
} 
Oliveira AS, Dias EM, Contato RG, Berzin F. Prevalence study of signs and symptoms of temporomandibular disorder in Brazilian college students. Braz Oral Res 2006;20(1):3-7.

need estimate in the population studied. Fonseca ${ }^{7}$ (1992) advocated that subjects classified as having severe or moderate TMD should be referred to a specialized health care center or specialist. However, Kuttila et al. ${ }^{13}$ (1997) evidenced that just 7\% of subjects classified as having severe or moderate TMD will require health care attention.

Different questionnaires covering major TMD signs and symptoms have been elaborated to simplify the evaluation in epidemiologic studies and to standardize research samples. Some of these questionnaires provide that subjects be classified by severity degree $e^{7,8,12}$. The anamnestic and clinical indexes proposed by Helkimo ${ }^{12}$ (1974) were obtained from clinical observations. Based on Helkimo's $^{12}$ (1974) indexes, Fonseca ${ }^{7}$ (1992) developed his anamnestic questionnaire that classifies TMD signs and symptoms as light, moderate or severe, or non-TMD. The author obtained a reliability of 95\% and a good correlation with Helkimo's index $(\mathrm{r}=0.6169, \mathrm{p}<0.05)$. Other advantages of Fonseca's $^{7}$ (1992) questionnaire are self-administration, short time of application, and low cost.

There are few TMD prevalence studies in Brazil, according to a review of the scientific literature. Garcia et al. ${ }^{9}$ (1997) evaluated 200 college students using Fonseca's ${ }^{7}$ (1992) questionnaire. The authors reported that 122 students $(61 \%)$ had some degree of TMD signs or symptoms, being $84(68.85 \%)$ of them women. Pedroni et al. ${ }^{18}$ (2003) evaluated 50 Brazilian college students using Fonseca's ${ }^{7}$ (1992) questionnaire. The authors reported that $68 \%$ of the volunteers had some degree of TMD. In $42 \%$ of them, TMD signs and symptoms were light; in $20 \%$, moderate; and in 6\%, severe.

The aim of the present study was to evaluate the prevalence and severity of temporomandibular disorders (TMD) in Brazilian college students from different federative regions.

\section{MATERIAL AND METHODS}

The volunteer participants of this study were randomly selected among college students from 15 cities distributed in each of the five Brazilian federative regions. The possibility of training a questionnaire administrator in the college institution and consent of the institution were the criteria to chose the colleges and cities that would take part in this study. All the volunteers were informed on the study aims, and they signed a formal consent prior to participation which was approved by the Research Ethics Committee. Brief information about TMD was given to volunteers. Those who had a clinical diagnosis of TMD, with or without treatment, and those who were undergoing orthodontic treatment during the period of data collection were excluded.

The volunteers were randomly selected according to the demographic data of the $2000 \mathrm{Bra}-$ zilian census (conducted by the Brazilian Institute of Geography and Statistics - IBGE) on the college population (Table 1). The five Brazilian federative regions were represented by 2,396 randomly chosen students, corresponding to $0.09 \%$ of Brazilian college students.

The questionnaire conceived by Fonseca ${ }^{7}$ (1992) was used to evaluate the degree of TMD in volunteers of this study, as it demonstrates a high efficiency in obtaining epidemiological data. This questionnaire contains an anamnestic index, and the volunteers were classified accordingly as light TMD, moderate TMD, severe TMD or non-TMD. The questionnaire consists of 10 questions, and the possible answers are "SOMETIMES", "YES" or "NO", with a single answer to be marked for each question. The results were analyzed using the frequency distribution of the questionnaire answers according to the anamnestic index proposed by

TABLE 1 - College students allotment in five Brazilian federative regions according to 2000 Brazilian census demographic data of the Brazilian Institute of Geography and Statistics (IBGE).

\begin{tabular}{l|c|c|c}
\hline \hline \multicolumn{1}{c|}{ Federative Regions } & $\begin{array}{c}\text { College Brazilian Students } \\
\text { (Absolute Number) }\end{array}$ & $\begin{array}{c}\text { College Students in Sample } \\
\text { Studied (Absolute Number) }\end{array}$ & $\begin{array}{c}\text { Relative Frequency } \\
\text { (Percent Values) }\end{array}$ \\
\hline North & 123,034 & 103 & 4.29 \\
\hline Center-West & 253,413 & 212 & 8.85 \\
\hline Northeast & 464,989 & 389 & 16.23 \\
\hline South & 580,937 & 486 & 20.28 \\
\hline Southeast & $1,441,474$ & 1,206 & 50.33 \\
\hline Total & $2,863,847$ & 2,396 & 100.00 \\
\hline \hline
\end{tabular}

Source: IBGE, Censo Demográfico de 2000 (microdados da amostra). http://www.ibge.gov.br/censo/numeros.shtm. 
Oliveira AS, Dias EM, Contato RG, Berzin F. Prevalence study of signs and symptoms of temporomandibular disorder in Brazilian college students. Braz Oral Res 2006;20(1):3-7.

TABLE 2 - Severity classification of TMD signal and symptom of the studied sample $(n=2,396)$.

\begin{tabular}{l|c|c|c|c|c}
\hline \hline & Total & Non-TMD & Light TMD & Moderate TMD & Severe TMD \\
\hline Age & $22.06 \pm 4.9$ & $22.22 \pm 4.7$ & $21.95 \pm 5.0$ & $21.89 \pm 5.2$ & $22.68 \pm 5.3$ \\
\hline Sample (Percent Values) & $100(\mathrm{n}=2,396)$ & $31.39(\mathrm{n}=752)$ & $50.38(\mathrm{n}=1,207)$ & $13.94(\mathrm{n}=334)$ & $4.30(\mathrm{n}=103)$ \\
\hline \hline
\end{tabular}

TABLE 3 - Severity classification of TMD signal and symptom of the studied sample for both sexes $(\mathrm{n}=2,396)$.

\begin{tabular}{l|c|c|c|c|c}
\hline \hline & Total & Non-TMD & Light TMD & Moderate TMD & Severe TMD \\
\hline Women & $100.00(\mathrm{n}=1,765)$ & $26.97(\mathrm{n}=476)$ & $52.46(\mathrm{n}=926)$ & $15.64(\mathrm{n}=276)$ & $4.93(\mathrm{n}=87)$ \\
\hline Men & $100.00(\mathrm{n}=631)$ & $43.74(\mathrm{n}=276)$ & $44.53(\mathrm{n}=281)$ & $9.19(\mathrm{n}=58)$ & $2.54(\mathrm{n}=16)$ \\
\hline \hline
\end{tabular}

Fonseca ${ }^{7}$ (1992). The positive answers ('yes' and 'sometimes') were summed. The percent values were compared between sexes and severity degrees by the Chi-square test. The $\mathrm{p}<0.05$ criterion was used to establish statistical significance.

\section{RESULTS}

In this study, $73.66 \%$ of women (mean age $21.9 \pm 5$ years) and $26.34 \%$ of men (mean age $22.4 \pm 4.8$ years) filled out the Fonseca ${ }^{7}$ (1992) questionnaire (Table 2).

The results showed a smaller rate of volunteers classified as being free of any TMD severity degree ( $p$ 0.05), according to the Fonseca ${ }^{7}(1992)$ anamnestic index. The rate of volunteers classified as light TMD was significantly greater $(\mathrm{p}<0.05)$ than that of volunteers with other TMD severity categories (severe, moderate and non-TMD).

The results showed a greater rate of men without TMD signs and symptoms (Table 3). The women exhibited some TMD degree $(73.03 \%)$ with a greater frequency than men $(56.26 \%)$. No significant differences was observed between sexes for a same severity degree $(p>0.05)$. There was no significant difference between those with some degree of TMD (56.25\%) and those classified as non-TMD (43.74\%) in men.

The female volunteers classified as light TMD were significantly more numerous $(\mathrm{p}<0.05)$ than those which fell under other TMD severity categories (severe, moderate and non-TMD). There was no significant difference between moderate TMD and non-TMD rates in women (Table 3 ). The male volunteers classified as severe TMD were significantly less numerous $(p<0.05)$ than those which fell under other TMD severity categories (light, moderate and non-TMD). There was no difference between sexes in a same severity category, but women presented greater rates in all categories (Table 3).

\section{DISCUSSION}

In this study the amount of volunteers with some TMD severity degree was higher than nonTMD subjects. Similar results were found by Pedroni et al. ${ }^{18}$ (2003) (32\%), Schiffman ${ }^{19}$ (1990) (25\%), Locker, Slade ${ }^{15}$ (1989) (33\%), and Grosfeld et al. ${ }^{11}$ (1985) (28\%) for non-TMD subjects. However, Conti $^{4}$ (1993) and Shiau, Chang ${ }^{20}$ (1992) related a greater amount of non-TMD subjects in their studies, $58 \%$ and $59 \%$ respectively.

The light TMD degree was the most prevalent category for female and male Brazilian college students. Dekon et al. ${ }^{5}$ (2002) and Pedroni et al. ${ }^{18}$ (2003) found similar results, also using the Fonseca questionnaire to evaluate the prevalence of TMD signs and symptoms in Brazilian college students. However, their samples were smaller.

In this study, the prevalence of the severe TMD degree was $4.30 \%$ for both sexes. Agerberg, Inkapööl ${ }^{2}$ (1990) and Kuttila et al. ${ }^{13}$ (1997) related that the severe TMD rate in non-patient samples ranged from 12 to $16 \%$.

Fonseca $^{7}(1992)$ advocated that subjects classified as severe and moderate TMD must be referred to a specialized health care center or specialist. Thus, according to our results, $18.24 \%$ of the volunteers, corresponding to a projection of 522,365 among all Brazilian college students, must be referred to treat their TMD signs and symptoms. However, as Kuttila et al. ${ }^{13}$ (1997) point out, only $7 \%$ of subjects classified as having severe or moderate TMD will require health care attention in Sweden. There is not a Brazilian estimate of suitable referrals concerning TMD. According to the results of this study and to those of Kuttila et 
Oliveira AS, Dias EM, Contato RG, Berzin F. Prevalence study of signs and symptoms of temporomandibular disorder in Brazilian college students. Braz Oral Res 2006;20(1):3-7.

al. ${ }^{13}$ (1997), a projection of 36,566 Brazilian college students would require health care attention. However, longitudinal studies should be undertaken to establish a reliable estimate since some subjects classified as TMD patients will present remission of their signs and/or symptoms ${ }^{8}$.

According to the results of this study, there is a greater probability of finding some degree of TMD severity in female college students than in male college students. Among non-patients, TMD signs and symptoms rates are about similar between sexes $^{12,16}$. In this study, no differences were found between sexes regarding positive answers to all the Fonseca questions in a same severity category. These results are consistent with those of Magnusson et al. ${ }^{16}$ (2000), Kuttila et al. ${ }^{13}$ (1997), Agerberg, Inkapööl ${ }^{2}$ (1990), and Locker, Slade ${ }^{15}$ (1989).

Some investigations look for explanations for the greater prevalence in women. Warren, Fried ${ }^{23}$ (2001) related morphological changes in TMJs of women by means of tomographic studies. Sipila et $a .^{21}(2001)$ related that women had more depressive episodes than men. LeResche et al. ${ }^{14}$ (1997) reported that women were more sensitive to pain. According to these authors, the TMJ estrogen receptors and the changes of hormonal levels caused by menstrual cycles influence the pain threshold in women. Other authors have related that women answer positively to a greater number of questions

\section{REFERENCES}

1. Agerberg G, Carlsson GE. Functional disorders of the masticatory system. II - Symptoms in relation to impaired mobility of the mandible as judged from investigation by questionnaire. Acta Odontol Scand 1973;31(6):33747.

2. Agerberg G, Inkapööl M. Craniomandibular disorders in an urban Swedish population. J Craniomandib Disord Facial Oral Pain 1990;4(3):154-64.

3. Agerberg G, Sandstrom R. Frequency of occlusal interferences: a clinical study in teenagers and young adults. J Prosthet Dent 1998;59(2):212-7.

4. Conti PCR. Avaliação da prevalência e etiologia das disfunções crânio-mandibulares em estudantes universitários e pré-universitários da cidade de Bauru - SP [Tese de Doutorado]. Bauru: Faculdade de Odontologia de Bauru da USP; 1993.

5. Dekon SFC, Fajardo RS, Zavanelli AC, Beleeiro RP, Pelisser J. Estudo comparativo entre índice anamnético de DTM e inventário de ansiedade traço-estado (IDATE). JBA: J Bras Oclusão, ATM Dor Orofac 2002;2(7):224-7.

6. Dworkin SF, LeResche L. Research Diagnostic Criteria for temporomandibular disorders: review, criteria, examinations and specifications, critique. J Craniomandib Disord 1992;6(4):301-55. because they are more careful and attentive to their health status than men ${ }^{1}$.

\section{CONCLUSIONS}

According to the results obtained, we concluded that:

1. Among Brazilian college students, there is a prevalence of signs and symptoms of TMD in both sexes similar to that reported in the literature;

2. women showed a greater prevalence of signs and symptoms of TMD than men;

3. Brazilian college students (women and men) classified as having light TMD were more numerous in this sample;

4. the TMD prevalence in Brazilian college students was similar to that reported by other studies found in the literature reviewed, and

5. longitudinal studies are recommended to follow the prevalence and health care needs of this population.

\section{ACKNOWLEDGMENTS}

We wish to thank the Foundation for the Improvement of Higher Education Personnel - CAPES for the financial support given by the PRO-SUP program.

7. Fonseca DM. Disfunção Craniomandibular (DCM): diagnóstico pela anamnese [Dissertação de Mestrado]. Bauru: Faculdade de Odontologia de Bauru da USP; 1992.

8. Fricton JR, Olsen T. Predictors of outcome for treatment of temporomandibular disorders. J Orofac Pain 1996;10(1):5465.

9. Garcia AR, Lacerda Jr N, Pereira SLS. Grau de disfunção da ATM e dos movimentos mandibulares em adultos jovens. Rev Assoc Paul Cir Dent 1997;51(1):46-51.

10. Gray RJ, Davies SJ, Quayle AA. A clinical approach to temporomandibular disorders. Br Dent J 1994;176(11):42935.

11. Grosfeld O, Jackowska M, Czanercka B. Results of epidemiological examinations of temporomandibular joint in adolescents and young adults. J Oral Rehabil 1985;12(2):95-105.

12. Helkimo M. Studies on function and dysfunction of the masticatory system. II Index for anamnestic and clinical dysfunction and occlusal state. Swed Dent J 1974;67(2):101-21.

13. Kuttila M, Kuttila S, Niemi PM, Alanen P, Le Bell Y. Fluctuation of treatment need for temporomandibular disorders and age, gender, stress, and diagnostic subgroup. Acta Odontol Scand 1997;55(6):350-5. 
Oliveira AS, Dias EM, Contato RG, Berzin F. Prevalence study of signs and symptoms of temporomandibular disorder in Brazilian college students. Braz Oral Res 2006;20(1):3-7.

14. LeResche L, Saunders K, Von Korff MR, Barlow W, Dworkin SF. Use of exogenous hormones and risk of temporomandibular disorder pain. Pain 1997;69(1-2):15360.

15. Locker D, Slade G. Association of symptoms and signs of TM disorders in an adult population. Community Dent Oral Epidemiol 1989;17(3):150-3.

16. Magnusson T, Egermark I, Carlsson GE. A longitudinal epidemiologic study of signs and symptoms of temporomandibular disorders from 15 to 35 years of age. J Orofac Pain 2000;14(4):310-19.

17. Oliveira AM. Caracterização Multifatorial de uma População de Portadores de Desordens Temporomandibular [Tese de Doutorado]. Piracicaba: Faculdade de Odontologia de Piracicaba da UNICAMP; 2002.

18. Pedroni CR, Oliveira AS, Guaratini MI. Prevalence study and symptoms of temporomandibular disorders in university students. J Oral Rehabil 2003;30(2):283-9.
19. Schiffman EL. The prevalence and treatment needs of subjects with temporomandibular disorders. J Am Dent Assoc 1990;120(3):295-303.

20. Shiau YY, Chang C. An epidemiological study of temporomandibular disorders in university students of Taiwan. Community Dent Oral Epidemiol 1992;20(1):20-43.

21. Sipila K, Veijola J, Jokelainen J, Jarvelin MR, Oikarinen KS, Raustia AM, et al. Association between symptoms of temporomandibular disorders and depression: an epidemiological study of the Northern Finland 1966 Birth Cohort. Cranio 2001;19(3)183-7.

22. Wänman A, Agerberg G. Etiology of Craniomandibular Disorders: Evaluation of Some Occlusal and Psychosocial Factors in 19-year-olds. J Craniomandib Disord 1991;5(1):35-44.

23. Warren MP, Fried JL. Temporomandibular disorders and hormones in women. Cells Tissues Organs 2001;169(3):187-92.

Received for publication on Apr 08, 2005

Sent for alterations on Sep 21, 2005

Accepted for publication on Dec 06, 2005 